\title{
曲げ破壊試験法で測定したソーダ・石灰ガラスの応力腐食特性
}

\author{
西田俊彦・吹擧昌宏・西川友三 \\ (京都工芸繊維大学 工芸学部 工業化学科)
}

頂角 $60^{\circ}, 90^{\circ}$ 並びに $120^{\circ}$ のシェブロンノッチを導入したソーダ・石灰ガラス試片を 3 点曲げ法 で破壊した。破壊試験は一定変位条件下で, 大気中, 乾燥空気中, 並びに減圧大気中で行った。そ してそのときの安定破壊の荷重緩和曲線をコンプライアンス法で解析し $K_{1}-V$ の関係を得た.

この試験法の長所としては (a) 試片の形状が単純で小形でよい, (b) プレクラックの作業が不要で ある, (c) 破壊方式が単純なので雾囲気制御がしやすい, などが挙げられる. そ枕え, この試験 法は，セラミックスのようなぜい性材料の臨界応力未満でのき裂成長を評価するために有効である うと考えられた。

(1983 年 8 月 11 日受付)

\section{Stress Corrosion Characteristics of Soda- Lime-Silicate Glass Measured by Bending Test}

\author{
Toshihiko NISHIDA, Masahiro FUKIAGE and Tomozo NISHIKAWA \\ (Department of Chemistry, Kyoto Institute of Techology \\ Matsugasaki, Sakyo-ku, Kyoto-shi 606
}

The specimens of soda-lime-silicate glass containing a chevron notch with the angle of $60^{\circ}, 90^{\circ}$ and $120^{\circ}$ were fractured by three-point bending with test span of $90 \mathrm{~mm}$. The fracture tests were carried out under a constant deflection in air, dried air or reduced pressures at room temperature. The stress intensity factor $K_{\mathrm{I}}$ was calculated from the compliance analysis of load relaxation curves, and the corresponding crack velocity $V$ was calculated also by comparing the theoretical compliance of the cracked specimen with the observed variation of the compliance with time during the load relaxation process. The following results were obtained :

(1) From the experiment of crack monitoring, it was clarified that, for chevron-notched specimens with crack under propagation, the stress condition during fracture changes gradually from plane stress to plane strain as the crack propagates.

(2) The crack propagation charactristics of soda-lime-silicate glass obtained from the present work agreed fairly well with those from other experimental techniques such as double cantilever beam and double torsion.

( 3 ) The reaction order of the glass with water vapor was almost unity in the range of watervapor pressure studied in the present work (0.003-16 Torr).

The method described above has the following advantages to measure the $K_{\mathrm{I}}-V$ relation for brittle ceramic materials: (a) simple, small and inexpensive test specimens, (b) no precracking required for stable fracture, (c) easy experimental technique with easy control of environmental conditions because of simple bending. This method is suitable, therefore, for measuring the $K_{1}$ $-V$ relation in the wide range of crack velocity, and serves the measurement of the subcritical crack growth in brittle ceramic materials.

[Received August 11, 1983]

Key-words : Stress corrosion, Fatigue, Chevron notch, Soda-lime-silicate glass, Bend test, Compliance analysis, Stress intensity factor, Crack velocity

\section{1. 緒言}

ガラスが水の存在下で応力腐食割れ (Stress Corrosion Cracking）を生じることは良く知られている。こ
の応力腐食現象は, 材料強度の時間的変化, つまり材料 がぜい性破壊に至るまでの時間（寿命）を予測するうえ で非常に重要な現象であり, き裂先端の応力拡大係数と 
そのときのき裂進展速度との関係 $\left(K_{\mathrm{I}}-V\right.$ 関係) で定量 化される。七ラミックスやガラスのようなぜい性材料に ついての $K_{\mathrm{I}}-V$ 関係は、これまでの Double Torsion 法 や Double Cantilever Beam法等の破填力学的手段に よって測定されてきた1)。これらの試験法は $K_{\mathbf{I}}-V$ 関係 の詳細を得るためには重要な役割を果たしてきたが，一 方では，試片の形状が特殊であったり，測定に際して特 別な治具を要したり，あるいは測定の操作が複雑であっ たりして，今後更に改良していかなければならない点も 数多く見いだされる2).

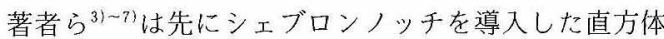
試片を一定変位速度下並びに一定変位下で曲げ破壊し， その際の破壊荷重の時間的変化をコンプライアンス法で 解析することによって，比較的容易に $K_{\mathrm{I}}-V$ 関係が求め られることを示した。この方法には，実験技術の簡便さ とともに，材料の曲げ強度測定用として広く一般に普及 している材料試験機亡測定治具，試片，並びに試験技術 を、ほぼそのまま利用できるという長所が見いだされた。 そこで本報では，これまで充力腐食の研究において最も 数多くの研究者に取り扱われてきたりーダ・石灰ガラス を試料亡して選び，上述の方法で $K_{1}-V$ 関係を求めて応 力鹰食反応の機構を論ずるとともに，他の試験法による 既報值との比較を通して，本武験法の特色を整理するこ とにした

\section{2. 实験方法}

フロートガラス板中より直方体を切り出し, 切断面を ダイヤモンド砥石（\#400）をつけた平面研削盤で形を 整えて $10 \times 10 \times 100 \mathrm{~mm}$ の寸法に仕上げた。次にこれら の試片の長手方向の中央部を刐厚 $0.3 \mathrm{~mm}$ のダイヤモン ド薄刃で 2 度切りし，試片の幅の一辺を底辺とし，頂角 が $60^{\circ} ， 90^{\circ} ， 120^{\circ}$ の二等辺三角形が残るようにシェブ ロンノッチを入れた。，ッチ加工によって切り残された 三角形部分を以下リガメントと呼ぶ。図1(a)には $90^{\circ}$ シェブロンノッチ試片の外観，図 1 (b)には破壊が進行中 の試片の断面図を示した。断面図には，後に示すコンプ

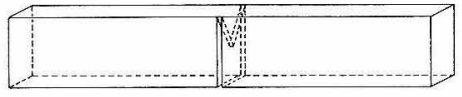

(a)

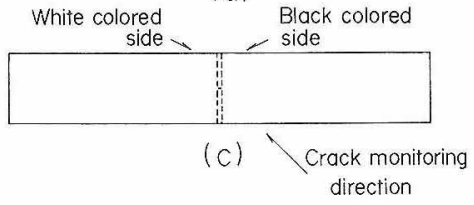

Fig. 1. Specimen with chevron notch for three-point bend test.

(a): Whole configuration, (b) : Cross section of notched area with crack under propagation, (c) : Top view of the specimen and crack monitoring direction
ライアンス解析 ${ }^{41,51,71}$ に必要なパラメーターである進展 したき裂長さ(a)を記入した。またガラスを試片とする場 合には，き裂進展の様子を外部から観察することが可能 なので，図1(c)に示したように曲げ破壞中の試片と水平 でノッチ面と $45^{\circ}$ の位置に接写用カメラを置いて，破壊 の様子を連続的に記録した。なおこの場合，き裂が進展 した部分とそうでない部分をはっきり識別できるよう に，武片の後方側面をノッチ面を境にして黒と白に塗り 分けておいた。

$K_{\mathrm{I}}-V$ 関係を求めるために，試片は図 2 に示す一定変 位下での曲げ破壊装置で，下部スパン $90 \mathrm{~mm}$ の条件で 3 点曲げ破壊した。すなわち試片をセットした後，上部 のマイクロメーターを操作して，すばやく試片に適当量 の曲げ変位 $\left(U_{\mathrm{S}}(P)\right.$ * を与えた。しして破壊に伴う荷重 緩和を下部のロードセルで検出し，その時間的変化をレ コーダーに記録した。图 3 に測定中に見られた皿型的な 2 種の荷重緩和曲線を示した。同図中には緩和過程に対

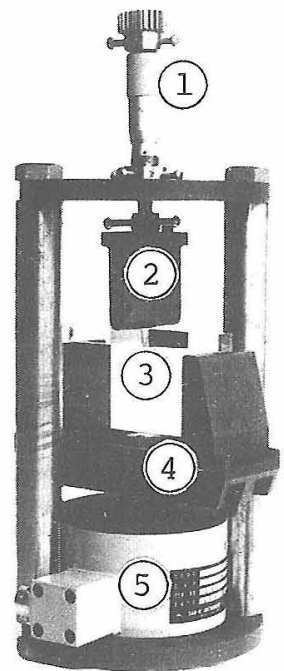

Fig. 2. Apparatus for three-point bend test under a constant deflection.

1 : Micrometer, 2 : Upper knife edge, 3 : Specimen with chevron notch, 4 : Bace with lower knife edges, 5 : Load cell

*シェブロンノッチ入りガラス試片の曲げ破壊荷重は，本荚 験条件下ではせいぜい $15 \mathrm{~N}$ 程度であった，低荷重範囲での測定 であるので試験機本体のたわみは無視できたが，治具上試片の 接触部分で生ずる荷重依存性変位 $U_{\mathrm{M}}(P)$ を考慮する必要が生 じた. 武片に変位を与えた際のマイクロメーターの送り $U_{\mathrm{m}}$ は, 試片自身の変位 $U_{\mathrm{S}}(P)$ と $U_{\mathrm{M}}(P)$ との和, $U_{\mathrm{m}}=U_{\mathrm{s}}(P)+U_{\mathrm{M}}(P)$ である. $U_{M}(P)$ は測定系固有のものであるので，ノッチを入れ る前のガラス角棒を装置中において，破壊実験と同じ手順，同 じ荷重範囲にわたって曲げ試験を行い，弾性計算による 3 点曲 げ試験時の荷重点変位 $U_{5}(P)$ を上式に代入して $U_{\mathrm{M}}(P)$ をあら かじめ求めておいた. 後に示すコンプライアンス計算に使用し た武片のたわみ量は $U_{\mathrm{m}}$ ではなくて， $U_{\mathrm{m}}-U_{\mathrm{M}}(P)$ として補正さ れた $U_{\mathrm{s}}(P)$ である。 


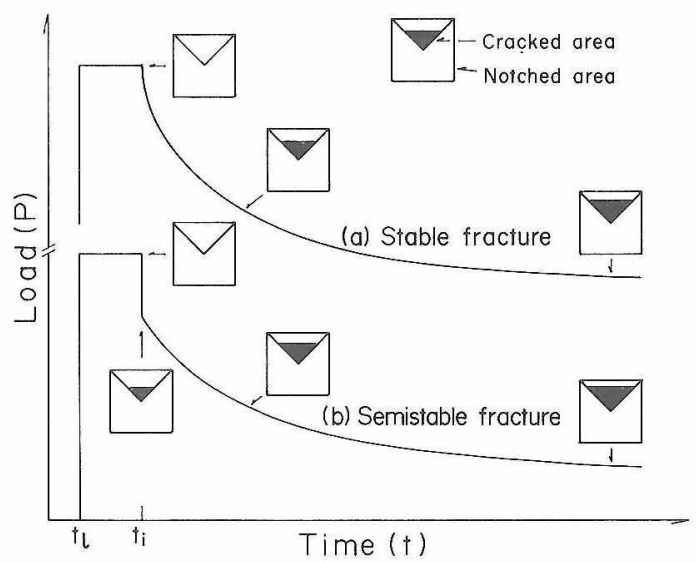

Fig. 3. Typical load relaxation curves and corresponding propagated cracks of soda-lime-silicate glass with chevron notch.

(a) : Stable fracture, (b): Semi-stable fracture

応したリガメント中のき裂進展状況を模式的に記入し た。試片に適当量の曲げ変位をすばやく与えて放置して おくと(図 3 の $t_{1}$ )，リガメント三角形の先端部での静 的疲労効果によって数分後に円滑なき裂の進展が開始し

(図 $3 \omega t_{i}$ ), その後数時間にわたって安定な荷重緩和 が続いた(図 3 の曲線(a)). 一方試片に曲げ变位を与え すぎたり，静的疲労効果の生しにくい環境条件下での測 定時等に，破壊を開始させるためにやむをえず変位を大 きくしたりすると,破壊の開始部分が不安定破增となる， いわゆる準安定破壊をしやすかった（図３の曲線(b))。

得られた安定破壇曲線，ないしは準安定破壊曲線の安 定破壊部分を（1)式（2）式でコンプライアンス解析 し**， $K_{\mathrm{I}}-V$ 関係を得た ${ }^{4), 81}$.

$$
\begin{aligned}
& K_{\mathrm{Ik}}=\sqrt{\frac{E^{\prime}}{2} \cdot \frac{\mathrm{d} \lambda_{\mathrm{k}}}{\mathrm{d} A_{\mathrm{k}}}} \cdot P_{\mathrm{k}} \\
& V_{\mathrm{k}}=\frac{\mathrm{d} a_{\mathrm{k}}}{\mathrm{d} t_{\mathrm{k}}}
\end{aligned}
$$

ここで $E^{\prime}$ は平面応力状態でヤング率 $E$ ，平面ひずみ状 態で $E /(1-\nu), \nu$ はポアソン比， $\lambda_{\mathrm{k}}$ は試片のコンプラ イアンス $\left(U_{s}\left(P_{\mathrm{k}}\right) / P_{\mathrm{k}}\right) ， a_{\mathrm{k}}$ は図1(b)に示したき裂長さ， $t_{\mathrm{k}}$ は時間，そして $A_{\mathrm{k}}$ はノッチ角 $\theta$ を使って $A_{\mathrm{k}}=a_{\mathrm{k}}^{2}$ $\tan (\theta / 2)$ 亡いう幾何学的な関係を使って求められるき 裂面積である。

破壊実験は $26^{\circ} \sim 29^{\circ} \mathrm{C}$ の室温大気中，乾燥空気中，並 びに娍圧下で行った。減圧条件下での奏験は図 2 に示し た装置全体を大型のデシケーター中に移し，真空ポンプ で脱気しながら測定を行った。をしてそれらの条件下で の䨌囲気中の水烝気分圧は $(3)$ 式で算出した。

**前報31-51,7)では一定变位速度下での曲げ破壞試験につい てのコンプライアンス計算法を示してある. 本実験は一定変位 試験であるが, 变位速度が非常に遅くなった一定変位速度試験 であると考えれば，解析手順は全く同じである.

$$
x=\frac{P_{\mathrm{x}} P_{\mathrm{S}}}{760} \cdot \frac{H_{\mathrm{r}}}{100}
$$

ここで $P_{\mathrm{x}}$ は測定環境の圧力， $P_{\mathrm{s}}$ は测定温度に対応す る水の飽和蒸気圧，そして $H_{\mathrm{r}}$ は相対湿度である。

\section{3. 实験結果と考察}

\section{1 シェブロンノッチ試片の破壊挙動}

シェブロンノッチ試片は，七ラミックスのようなぜい 性材料についても安定な破壞を可能にし，熱衝撃損傷抵

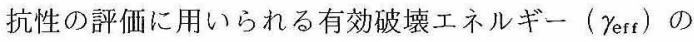
測定に利用されてきた名10).しかし今日まで，この試片 の破壊時に伴うき裂進展の様子を詳細に観察した例はな 6).

図4には，代表例として $90^{\circ}$ にシェブロンノッチ試片 の破壞前（図 4(a)) 並びにき裂進展中（図 4(b〜f)) の リガメント部分の写真を示す．実験方法のところで述へ たように，試片後方測面がノッチ面を境にして白と黒に 塗り分けてあるので, 破壊のないリガメント部分は白く, き裂が進展した部分は黒く見える.図4のような一連の 写真を参考にして， $60^{\circ} ， 90^{\circ}, 120^{\circ}$ シェブロンノッチ試 片のリガメント三角形上のき裂先端位置の時間的変化の 例をまとめて図5に示す。これらの図に共通して認めら れることは，破壊開始後しばらくの間，き裂がリガメン 卜三角形の底辺と平行な直線状であるのに対して，進展 するにつれて，中央部が先行し両端が遅れてくるために 弧を描く傾向のあることである. 破壞力学において, 平 板状試片中の 2 次元的なき裂に垂直に張力が与えられた とき，き裂先端の塑性域の大きさは，拘束の大きい中央
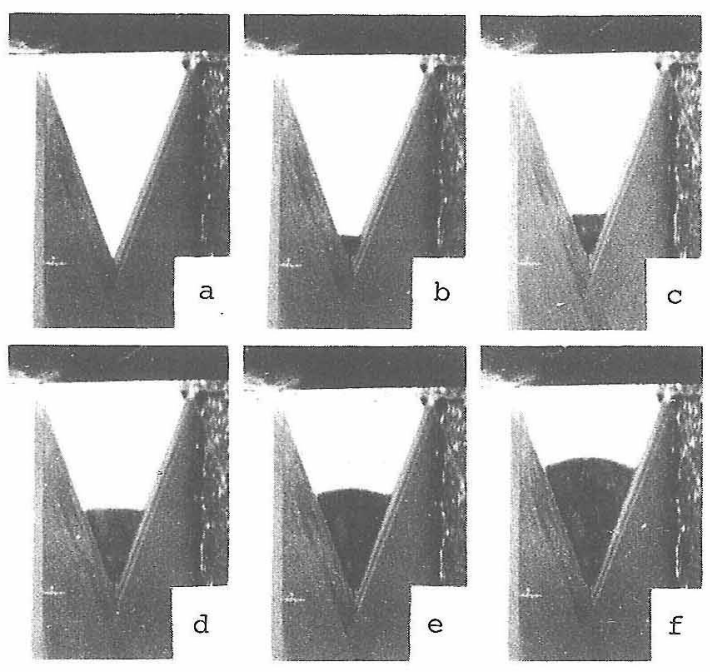

Fig. 4. Photographs of propagated crack in the ligament part of a specimen with chevron notch of $90^{\circ}$. Black parts are cracked area and white parts are area to be cracked. The time after crack initiation in (a) (f) are $0,10,100,400,1500$ and $6000 \mathrm{~s}$, respectively. 


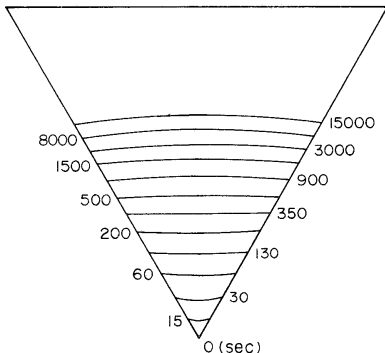

(a)

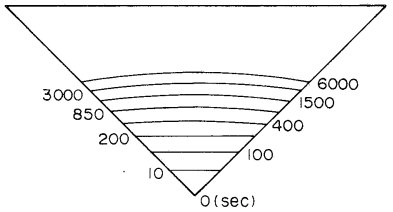

(b)

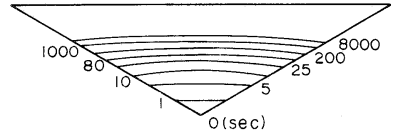

(c)

Fig. 5. Examples of the variation of a crack front profile with time in the specimens with chevron notch of (a) $60^{\circ}$, (b) $90^{\circ}$ and (c) $120^{\circ}$ fractured under a constant deflection.

部で小さく, 拘束の小さい表面部で大きくなることが知 られている。シェブロンノッチ試片の先端部近傍の破壊 は, うす板の破壊に相当するために平面応力状態が満足 され，き裂が進展するとともに板厚が増し，中央部に塑 性域の小さい平面ひずみ状態が満足されてくるのであろ う. その結果, き裂先端は塑性域の小さい平面ひずみ部 分でより大きな応力集中を生じ, 先行し始めると考えら れる. 図 5 に示したノッチ角の異なる種類の試片の比較 においても，ノッチ角の広い試片中のき裂の先端が進展 開始後比較的早く弧を描き始めており，上述の考察之一 致している.

厳密に考えると, 破壊の進行とともに応力状態が平面 応力から逐次平面ひずみに移行するのであれば，（2） 式の計算過程で使用する $E^{\prime}$ は, その移行の程度に応じ て適宜じで補正しなければならないし，また（3）式 の $V$ は, き裂先端全長にわたっての移動量の時間的変 化の平均值を求めなければならないであろう。しかし図 5 に見られるように，本測定条件の範囲内ではき裂先端 の曲がりは少ないので,これをほぼ直線であるとみなし， $E^{\prime}$ は計算の容易な平面応力状態を仮定し $\left(E^{\prime}=E\right), V$ もリガメント三角形の垂直二等分線上で求めた。

図6には $60^{\circ}, 90^{\circ}, 120^{\circ}$ シェブロンノッチ試片に見 られた安定破壊の荷重緩和曲線の典型例を示す。いずれ

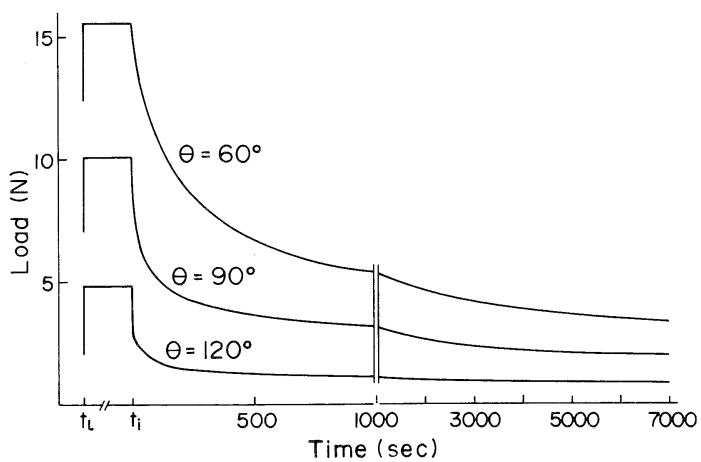

Fig. 6. Typical load relaxation curves of soda-limesilicate glass specimens with chevron notch of $60^{\circ}, 90^{\circ}$ and $120^{\circ}$ fractured under a constant deflection.
の試片でも最初に大きい緩和が起こり，時間の経過とと もに緩和が少なくなるが，詳細にみると，ノッチの角度 によって緩和の挙動が少しずつ異なっている。すなわち ノッチ角が広い場合は初期の荷重緩和が大きく，しばら くするとほとんど緩和しなくなる。一方，ノッチ角が狭 いと最初の緩和が割合少なく，長時間緩和が続く。この 破壊挙動の差は, き裂が進展していく過程での試片のコ ンプライアンス変化 $(\mathrm{d} \lambda / \mathrm{d} a)$, 並びに破壊面積変化 $(\mathrm{d} A / \mathrm{d} a)$ がノッチの角度によって異なるために生ず る.このことはノッチの形状を工夫することによって, 測定者が希望するき裂速度範囲での $K_{\mathrm{I}}-V$ 関係を特に丁 寧に測定することも可能であることを意味する.

\section{2 ソーダ・石灰ガラスの応力腐食の機構}

室温大気中並びに減圧下でのソーダ・石灰ガラスの $K_{\mathrm{I}}-V$ 関係を図 7 に示す。き裂の成長挙動は水蒸気分圧 にはっきりと依存している。ガラスが水の存在下で応力 腐食することは, 窒素一水蒸気混合気体中での Wiederhorn ら ${ }^{111,12)}$ の研究によって既に明らかにされて おり，き裂先端の $K_{\mathrm{I}}$ が変化するにつれて特徴的な三つ （領域 I 〜 III）のき裂進展挙動がみられると言われてき

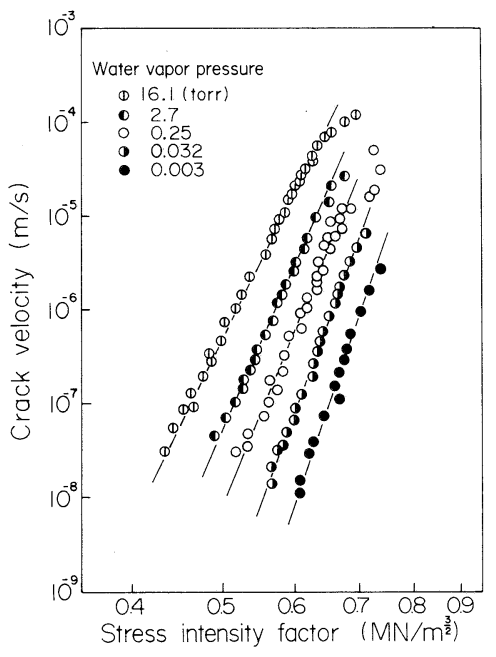

Fig. 7. $K_{\mathrm{I}}-V$ relations for soda-lime-silicate glass in air and under some reduced pressures. 
た。

領域 I（ $K_{\mathrm{I}}$ が低いところ）では，き裂先端への水の 拡散が水とガラスとの反応速度より速くなるので $V$ は 反応速度律速となる。領域 II $\left(K_{\mathrm{I}}\right.$ が上昇すると $V$ が $K_{\mathrm{I}}$ に依存せず一定值となる場合がある）では，水がき裂先 端へ供給される速度よりも化学反応の速度の方が速いの で，き裂成長は水の拡散律速となる。この二つの領域て は遅い方の機構が $V$ を律速するのである．更に $K_{\mathrm{I}}$ が増 大し $K_{\mathrm{Ic}}$ 近くになると, 破壊の進展挙動が環境に影響さ れない領域四がある。この領域の機構はまだ明確にされ ていない。

多くのセラミックスやガラスについて，領域 I , III データは $(4)$ 式で表現されている.

$$
V=\alpha K_{\mathrm{I}}^{N}
$$

ここで $\alpha, N$ は定数である。そしてガラスについての $K_{1}-V$ 関係のこう配 $(N)$ は, 領域 I で 10～30, 領域 III で 100 程度であろうと考えられている. 図 7 に示した本 実験結果のこう配は，19～25 の範囲にある．このこと は本実験条件のもとで, ソーダ・石灰ガラスが領域 I の 破壊挙動をし，水の分圧が減少しても領域 II， III の挙動 へ移行しなかったことを示す。前述のとおり，窒素-水 蒸気混合気体中での Wiederhorn らの詳細な研究では, ガラスの応力腐食特性は，水の分圧が減少するにつれて 領域 I の挙動から II 又はIII の挙動へと移行することが明 らかにされてきた。しかしこれらの研究は環境の分圧が 大気圧となっている場合であり，本実験のように減圧に よって水蒸気分圧を制御した場合には，応力腐食特性も 異なってくることが考えられる.このことは既に曽我ら ${ }^{13}$ によって指摘されている.すなわち彼らはDouble Torsion 法で減圧条件下でのソーダ・石灰ガラスの水に よる応力腐食特性を調へ，減圧条件下では領域 II， III 挙動が現れにくいことを実験的に確かめた。そしてその 原因として，水分子の平均自由行程と拡散係数が減圧効 果によって増大することを挙げている.

本実験も減圧の条件下であり，しかも $N$ が 25 以下と いう結果も得られているので，一応領域Ｉ（水とガラス の化学反応律速) の範囲での測定が行われたと考えても 良いであろう。すると Hilling とCharlesによって提案 され，Wiederhornによって改良された ${ }^{12)}(5)$ 式によっ てがラスと水との反応次数を決定することが可能とな る。

$$
V=\left(\frac{\beta x^{n}}{n}\right) \exp \left(\frac{-Q+\beta^{\prime} K_{\mathrm{I}}}{R T}\right)
$$

ここで $n$ は反応次数， $Q$ は化学反応の活性化エネル ギ一, $R$ は気体定数, $\beta, \beta^{\prime}$ は定数である. 図 7 におい てなるべく外そう值を用いなくても良い值として $K_{\mathrm{I}}=$ $0.6 \mathrm{MN} / \mathrm{m}^{3 / 2}$ を選んで求めたき裂進展速度の水蒸気分 圧依存性を図 8 に示す。図のこう配 $(n)$ は 0.90 となっ

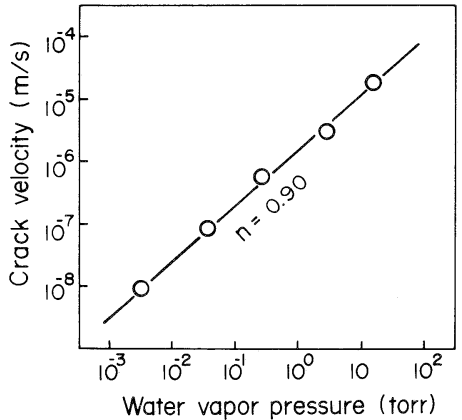

Fig. 8. $x-V$ relation for soda-lime-silicate glass at a constant $K_{\mathrm{I}}$ of $0.6 \mathrm{MN} / \mathrm{m}^{3 / 2}$.

ており，水とガラスの反応は，測定水蒸気分圧の範囲内 において，ほぼ 1 次反応であることを示唆していると考 えられる。

\section{3 他の試験法による測定結果との比較}

曲げ破壊試験法を用いて室温大気中並びに乾燥空気中 （大気圧）で測定したソーダ・石灰ガラスの応力腐食特 性を図 9 に示す。乾燥空気中の測定には市販の高純度空 気（露点 $\left.-60^{\circ} \mathrm{C}\right)$ を用いた。ただし測定系へ乾燥空気 を流入する際に若干の水分が大気中より混入している可 能性があり，それがどの程度なのかは本実験では正確に

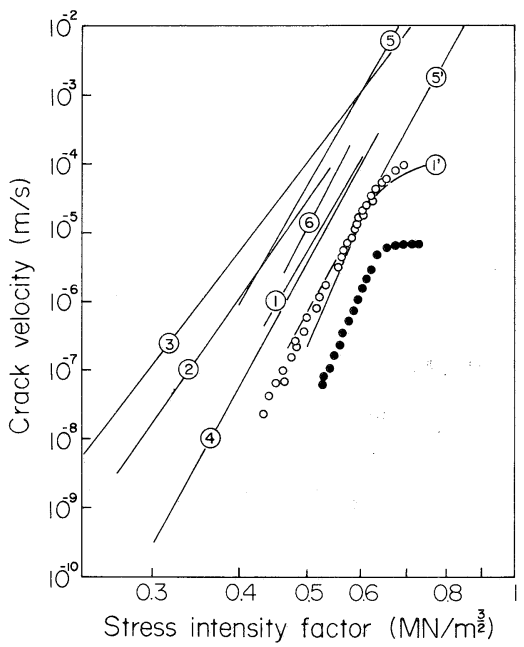

Fig. 9. $K_{\mathrm{I}}-V$ relation for soda-lime-silicate glass at room temperature.

1 : Measured by DCB in water at $25^{\circ} \mathrm{C}^{111}$,

$1^{\prime}$ : Measured by DCB in $30 \%$ rh at $25^{\circ} \mathrm{C}^{11)}$,

2 : Measured by DCB in water at $25^{\circ} \mathrm{C}^{12}$,

3 : Measured by DT in water at $25^{\circ} \mathrm{C}^{14}$,

4 : Measured by DCB in $50 \%$ rh at room temperature $^{15)}$,

5 : Measured by DT in water at $23^{\circ} \mathrm{C}^{16)}$,

$5^{\prime}$ : Measured by DCB in water at $23^{\circ} \mathrm{C}^{16}$,

6 : Measured by in water at $25^{\circ} \mathrm{C}^{13)}$,

$\bigcirc$ : Present work DT by bending test in $65 \% \mathrm{rh}$. at $26^{\circ} \mathrm{C}$,

: Present work by bending test in dried air at $25^{\circ} \mathrm{C}$ 
は分っていない。それでも減圧によって水分を制御した 場合（図７）に比べて明らかに異なった挙動として，領 域 II と考えられる水平部分が認められ，大気圧中では拡 散律速になりやすいことを示している．また同図中には 本実験の室温大気中の測定条件に比較的近いと考えられ るソーダ・石灰ガラスの応力腐食特性の報告值 ${ }^{11)}$ (6) 比較のために記入した。ソーダ・石灰ガラスのように， 入手経路による物性值のばらつきが小さいと考えられる 材料を対象とした場合でさえ，各測定デー夕相互間には かなりの開きが認められる。そしてそのことを考慮する と本報で示した試験方法による测定結果も従来法による 結果とおよそ良く一致していると考えて良いであろう.

セラミックスやガラスのようなぜい性材料について も, 工学的応用の立場上り, その力学的性質を体系的に 表現していく作業が急がれている.しかしながら，本報 で示した破壞力学的測定法を例にとっても，七ラミック ス材料に関しては, 試片寸法やその作製法, 具体的な測 定手順, データの取り方とその解析法等について統一し た取り決めが全くなされていないのが現状である。そし てそのことが測定結果を相互に比較し利用し合うことを むずかしくしているように思える. それらの点を含め て, セラミックスの機械的性質の評価法に関して, 今後 更に活発な議論を蓄積していくことが必要であろう。

\section{4. 総 括}

頂角 $60^{\circ}$, $90^{\circ}$ あるいは $120^{\circ}$ のシェブロンノッチを導 入したソーダ・石灰ガラス試片を下部スパン $90 \mathrm{~mm} の$ 3 点曲げで破壊した。破壊試験は一定変位条件のもと で，大気中，乾燥空気中，並びに減圧大気中のいずれも 室温であった，応力拡大係数 $\left(K_{\mathrm{I}}\right)$ は曲げ破壊荷重の 緩和曲線をコンプライアンス解析することによって求め た。これに対応するき裂速度 $(V)$ は，き裂進展中の試 片の理論コンプライアンスを, 荷重緩和過程中の試片の コンプライアンスの時間的変化と比較することによって 求めた。

以下の結論が得られた。

（1）き裂の進展を光学的に観察することにより， シェブロンノッチ試片の破壊中に, き裂先端の応力状態 が平面応力状態から平面ひずみ状態に移り変わっていく
ことが明らかとなった。

（2）本試験法で得たソーダ・石灰ガラスの応力腐食 特性は, 他の試験法による測定結果とかなり良い一致を 示した。

（3） ガラスと水の応力腐食反応の反応次数は本報の 水蒸気分圧の範囲(0.003 16 Torr)ではほぼ 1 次であっ た。

本報で示した曲げ破壊試験法によるぜい性材料の $K_{\mathrm{I}}-V$ 関係測定には次の長所が認められた。(a) 試片の 形状が単純かつ小形なので費用がかからない。(b) 安定 破壊のためのプレクラックは, 試験開始時の初期に自然 発生的に導入されてしまう。(c) 単純な曲げ破壊方式な ので試験が簡単で雾囲気制御もしやすい.

それゆえ本試験法は，広いき裂進展速度の範囲にわ たって，セラミックスのようなぜい性材料の応力腐食の 問題を評価するために有効であろうと考えられた。

\section{文献}

1) S.M. Wiederhorn, "Subcritical crack growth in ceramics", in Fracture mechanics of ceramics, Vol.2, Ed by R. C. Bradt, D. P. H. Hasselman and F.F. Lange, Plenum Press (1974) p. 613-46.

2) T. T. Shin and J.Opoku, Eng. Fract, , Mech., 12, 479-98 (1979).

3）西田俊彦，西川友三，窟協，89, 544-50 (1981).

4）西田俊彦，植田邦義，林 国郎，西川友三，䇺協， 90 , 14-19 (1982).

5）西田俊彦, 武井喜樹, 西川友三, 窯協, 90, 254-61 (1982).

6）西田俊彦，西川友三，窯協，90，282-83 (1982).

7) T. Nishida and T. Nishikawa, Proc. 25th Japan Congl. Mater. Res. (1982) p. 224-29.

8) A. G. Evans, "Fracture mechanics determination" in Fracture mechanics of ceramics, Vol.1, Ed. by R. C. Bradt, D. P. H. Hasselman and F. F. Lange, Plenum Press. (1974) p. 17-48.

9) J. Nakayama, J. Am. Ceram. Soc., 48, 583-87 (1965).

10) H. G. Tattersall and G. Tappin, J. Mater. Soc., 1, 296-301 (1966).

11) S. M. Wiederhorn, J. Am. Ceram. Soc., 50, 407-14 (1967).

12) S. M. Wiederhorn and L.H. Bolz, ibid., 53, 543-48 (1970).

13) N. Soga, T. Okamoto, T. Hanada and M. Kunugi, ibid., 62, 309-40 (1979).

14) A. G. Evans, J. Mater. Sci, , 7, 1137-46 (1972).

15）文献 1 ) 中の p. 630.

16) D. K. Shetty, A. V. Virker and M. B. Haward, J. Am. Ceram. Soc., 62, 307-09 (1979). 